\title{
The Cost Efficiency of Takaful Insurance Companies*
}

\author{
Hale Abdul Kader ${ }^{\mathrm{a}}$, Mike Adams ${ }^{\mathrm{b}}$ and Philip Hardwick ${ }^{\mathrm{c}}$ \\ ${ }^{a}$ Centre for Risk \& Insurance Studies (CRIS), Nottingham University Business School, University of \\ Nottingham, Jubilee Campus, Nottingham NG8 1BB, U.K. \\ E-mail: lixha8@nottingham.ac.uk \\ ${ }^{\mathrm{b}}$ School of Business and Economics, Swansea University, Singleton Park, Swansea SA2 8PP, U.K. \\ E-mail: m.b.adams@swansea.ac.uk \\ ${ }^{\mathrm{c}}$ Business School, University of Bournemouth, Fern Barrow, Poole BH12 5BB, U.K. \\ E-mail: phardwic@bournemouth.ac.uk
}

This study examines the cost efficiency of non-life Takaful insurance firms operating in 10 Islamic countries. Non-parametric data envelopment analysis is used to compute cost efficiency scores and a second-stage logit transformation regression model is then estimated to test the influence of corporate characteristics on these efficiencies. We find that nonexecutive directors and separating the Chief Executive Officer and Chairman functions do not improve cost efficiency. However, board size, firm size and product specialisation have positive effects on the cost efficiency of Takaful insurers. In contrast, the regulatory environment is found not to be statistically significant in terms of improving cost efficiency. We conclude that our results could have important commercial and policy implications. The Geneva Papers (2010) 35, 161-181. doi:10.1057/gpp.2009.33

Keywords: takaful insurance; cost efficiency; corporate governance

\section{Introduction}

This study examines the cost efficiency of (non-life) Takaful insurance firms operating in 10 Islamic countries. ${ }^{1}$ Non-parametric data envelopment analysis (DEA) is used to compute cost efficiency scores and a second-stage logit transformation regression model is estimated to test the influence of corporate characteristics on these scores. To our knowledge, this is the first study of its kind to focus on the Takaful insurance industry - a sector that has unique institutional features which reflect underlying Islamic principles and norms of behaviour. In this regard, our study follows a wellestablished stream of insurance industry efficiency studies conducted in developed Western insurance markets such as New Zealand, ${ }^{2}$ the United Kingdom (U.K.), ${ }^{3}$ and

\footnotetext{
* We acknowledge the help of Chakib Abouzaid and Hong Zou during the course of this study. The financial support of Takaful Re is also very much appreciated. However, the usual disclaimer applies.

${ }^{1}$ We focus on non-life Takaful insurers as life (family) and medical/disability insurance is usually longterm in nature and often involves a savings element (Maysami and Kwon, 1999). As such, Takaful life insurance business, like its counterpart in Western insurance markets, is inherently different from nonlife insurance business and so we argue that it should be treated separately from the non-life sector in efficiency studies.

${ }^{2}$ Khaled et al. (2001).

${ }^{3}$ Hardwick (1997).
} 
the United States (U.S.), ${ }^{4}$ and indeed, elsewhere (Taiwanese insurance industry study). ${ }^{5}$ We focus on cost rather than profit efficiency for two main reasons. First, data limitations (e.g., on output prices) preclude us from computing profit efficiency measures; and second, determining the profits of Takaful insurers is subject to Shari'a law, particularly the limitations placed on usury, and other institutional factors such as the lack of liquid markets for Islamic securities. ${ }^{6}$ In view of these constraints, optimizing operational cost efficiency is likely to be a particularly important business objective for Takaful insurers.

Our decision to focus on cost efficiency measures of performance in the Takaful insurance industry is further motivated by their importance in operational and strategic decision-making, as well as the limitations of alternative accounting-based financial ratio measures of insurance industry performance. For example, compared with economic (input) efficiency measures, accounting-based measures of corporate performance are deficient because they combine both input and output efficiencies and so distort the measurement and analysis of efficiency performance. ${ }^{7}$ Variations in the accounting and actuarial practices used by insurance companies can also complicate comparisons of reported financial performance. ${ }^{8}$ Therefore, focusing on economic rather than accounting-based measures of performance helps to avoid potentially confounding effects emanating from differences in companies' treatment of accounting items and their reporting of annual earnings. Furthermore, direct market measures of economic performance (e.g., excess stock returns or the market-to-book ratio) are typically not very useful given that many Takaful insurers are not publicly listed. As a result, investigating the relation between cost efficiency and corporate governance and other firm-specific variables (e.g., ownership structure) in the international Takaful insurance industry could help to determine the economic drivers of firm value. ${ }^{9}$ Our research results could also have potentially important policy implications. For example, empirical evidence highlighting the linkage between board structure and cost efficiency could enable regulators to decide whether or not to improve (or supplement) the existing governance mechanisms of Takaful insurers by enhancing licensing and/or solvency requirements.

Bhatty ${ }^{10}$ reports that Takaful insurance is growing rapidly in Islamic countries, particularly in the Middle East - accounting for about 80 per cent of annual premiums in 2006, and East Asian countries such as Malaysia and Indonesia - contributing about 12 per cent of annual premiums in the same period. ${ }^{11}$ Swiss $\mathrm{Re}^{12}$ report that in 2007 Islamic countries accounted for 23 per cent of emerging markets gross domestic product (GDP) and some 11 per cent of annual insurance premiums (roughly US $\$ 45$

\footnotetext{
${ }^{4}$ (For example Cummins and Zi (1998); Cummins (1999); Cummins and Weiss (2000).

${ }^{5}$ For example Wang et al. (2007).

${ }^{6}$ Abouzaid (2007); Swiss Re (2008).

${ }^{7} \mathrm{Pi}$ and Timme (1993).

${ }^{8}$ Klumpes (2005).

${ }^{9}$ For example, see Zheka (2005).

${ }^{10}$ Bhatty (2007).

${ }^{11}$ World Islamic Insurance Directory (2008).

12 Swiss Re (2008).
} 
billion). Swiss $\mathrm{Re}^{12}$ also note that over the period 2004-2007 the average annual rate of growth for Takaful insurance was estimated at 25 per cent compared with 10 per cent in the conventional international insurance market. Current estimates suggest that worldwide there are between 100 and 150 Takaful insurance carriers of varying size and complexity operating in nearly 30 countries including a handful of licensed operations in Europe. ${ }^{11,12}$

In view of the increasing growth and development of Islamic insurance markets we believe that by contributing insights into the factors that influence the cost efficiency of Takaful insurance companies our study helps to promote greater understanding of the economics of Takaful insurance. This attribute could be of interest to policy-holders, shareholders, industry regulators, and other stakeholders of Takaful insurance firms, and enable them to make better investment, risk and solvency management decisions.

While the technical aspects of underwriting Takaful insurance are similar to conventional insurance, the design of Takaful products has to conform to Islamic jurisprudence (Shari'a). ${ }^{12}$ In essence, Takaful insurance involves pooling individual risk exposures on an indemnity basis but without predetermined rates of interest (riba) and profit margins, which are both forbidden under Shari'a law. ${ }^{13}$ However, Islamic finance allows shareholders to participate in the surplus arising from the use of contributed insurance capital on a profit-sharing basis that has been agreed ex-ante with policy-holders. ${ }^{14}$ There are three main models of Islamic financing commonly used by Takaful insurers. The mudaraba model allows the capital provider (e.g., shareholder) to determine ex-ante the profit-sharing ratio with the capital user (e.g., insurance pool) but bear the full risk of losses. The musharaka mode of financing allows a capital user (e.g., insurance pool) to enter into agreement with a secondary capital supplier (e.g., reinsurer) but then share profits and losses in proportion to their respective capital contributions. The wakala model involves the capital provider (e.g., shareholder) charging the user (e.g., insurance pool) a fee to cover the costs of doing business (which can include recompense for the use of capital, advisory and support services, operational and investment expenses, and so on). Underwriting premiums are "donated" to the insurance pool and then used to settle claims. In this case, the surplus on the insurance pool is the excess of premiums over claims in a period; however, shareholders may sometimes be entitled to a return on the annual surplus arising on the insurance pool (conditional tabarru) in addition to their wakala fee. ${ }^{15}$ While Takaful insurance pools have many similarities with Western mutual insurance operations, ${ }^{12}$ their managers are, in addition to being unable to charge interest on capital, prohibited under the Shari'a from taking highly uncertain underwriting and speculative investment decisions (gharar). Managers of Takaful insurers must also invest surplus funds in Shari'a-compliant (halal) assets such as domestic public sector securities and the equities of Islamic financial institutions. However, as noted earlier, the shortage of Islamic investment opportunities and the

\footnotetext{
13 Khorshid (2004).

${ }^{14}$ Maysami and Kwon (1999).

${ }^{15}$ Kassim (2007).
} 
lack of market liquidity for Islamic securities can sometimes put downward pressure on reported annual profits. ${ }^{16}$ Abouzaid ${ }^{16}$ also points out that another potential problem that can affect the economic performance of Takaful insurers is the limited reinsurance capacity in many Islamic insurance markets, particularly in potentially highly volatile and difficult to assess insurance lines such as environmental risks. These considerations, together with the fact that financial services regulation and corporate governance in many Islamic jurisdictions often lags behind that of developed economies ${ }^{17}$ underscore the need for Takaful insurers to develop cost efficient operations as a prelude to effective long-term strategy.

As noted earlier, a key aspect examined in this study is the extent to which the cost efficiency of Takaful insurers is affected by corporate governance variables such as board size and composition. For example, Rediker and Seth ${ }^{18}$ report that firm-specific cost efficiencies will depend on how effective the system of corporate governance is in controlling and resolving incentive conflicts between owners (principals) and managers (agents). A sound system of governance could also help Takaful insurance firms to realise operational efficiencies and enhance economic performance by improving, for example, systems of resource allocation and product design, and innovation strategies, such as business restructuring initiatives. ${ }^{19}$ Wang et al. ${ }^{20}$ further report that the link between corporate governance and economic efficiency is particularly important in insurance companies given the distinctive nature of its business (e.g., in terms of its asset-liability structure, commitment to meet future claims, ownership structure, and so on).

The remainder of our paper is structured as follows. The next section provides definitions of cost efficiency and the subsequent section outlines the hypotheses to be tested. The fourth section discusses the DEA methodology used, the sources of data, measurement of the variables and the regression model employed. The penultimate section analyses the results and the final section concludes our paper.

\section{Definitions of efficiency}

For a given Takaful insurer, an overall cost efficiency score reflects both "technical" and "allocative" efficiency. Technical efficiency (TE) measures how efficiently technology is employed in the use of inputs to achieve a given level of output. ${ }^{21}$ Allocative efficiency (AE) refers to how efficiently management chooses the mix of inputs at given input prices. A production frontier shows the minimum quantity of

${ }^{16}$ Abouzaid (2007).

${ }^{17}$ Islam (2003).

${ }^{18}$ Rediker and Seth (1995).

${ }^{19}$ Thompson and Wright (1995).

${ }^{20}$ Wang et al. (2007).

${ }^{21}$ Takaful insurers' technology can include general computer systems, internet services, telephone sales, as well as actuarial and financial services technology such as profit emergence models and asset-liability management systems. Berger (1993) reports that such financial technology often relies heavily on the use of information technology to collect, process, and disseminate data, as well as economic and statistical models to analyse data. 
inputs needed to produce any given quantity of output for a perfectly efficient firm, while a cost frontier shows the minimum cost of producing any given quantity of output for a perfectly efficient firm. Takaful insurance firms may fail to reach the production and cost frontiers because of technical and/or allocative inefficienciesthat is, because they fail to get the best out of their inputs and/or they fail to employ the cost-minimising combination of inputs.

Technical efficiency can be further sub-divided into "pure technical efficiency" (PTE) and scale efficiency (SE). PTE measures how far a Takaful insurer is away from the production or cost frontier under conditions of variable returns to scale, while SE measures the relative production loss (or cost increase) caused by a deviation from constant returns to scale. Thus, scale inefficiency may be associated with either increasing returns to scale (economies of scale) or decreasing returns to scale (diseconomies of scale). More generally, we can describe a Takaful insurance firm as being cost efficient if its costs are equal to the costs of a "best practice" firm operating under the same conditions (i.e., producing the same output bundle with the same input prices). In this study, we compute cost efficiency scores for a sample of Takaful insurance firms using non-parametric DEA — see section 'DEA'

\section{Development of hypotheses}

Agency theory holds that corporate governance is concerned with the way that managerial performance is monitored and controlled to ensure compliance with owners' wealth maximisation objectives. ${ }^{22}$ The need for corporate governance thus emerges because of unresolved contracting incentive conflicts, particularly between managers and owners of firms. ${ }^{23}$ Zheka $^{24}$ also reports that systems of corporate governance essentially allow shareholders to be assured that managers in firms use shareholders' capital efficiently and ensure they receive a competitive return on their investment. In the modern corporation, the board of directors is charged with alleviating contracting incentive conflicts and ensuring that business performance is consistent with owners' wealth maximisation objectives. ${ }^{22}$ Therefore, the structure of corporate boards could influence the performance of Takaful insurance firms in areas such as their cost efficiency. The remainder of this section puts forward three pairs of relevant hypotheses for empirical testing.

\section{Non-executive directors}

To ensure alignment of contractual interests in firms, experienced non-executive (outside) directors can be employed to advise executive (inside) board members on strategic business matters including how to maximise operational cost efficiency. ${ }^{7,25}$

\footnotetext{
22 Nelson (2005).

23 Jensen and Meckling (1976).

24 Zheka (2005).

${ }^{25}$ As in Hossain et al. (2000, p. 266), we define non-executive directors in this study as board members who are identified from published sources as not active or retired employees of the Takaful insurance firm and do not have close business ties (e.g. as consultants) to that firm.
} 
Indeed, Perry and Shivdasani ${ }^{26}$ show that for U.S. firms facing poor operating performance (e.g., increased costs and decreasing returns on assets), a majority proportion of non-executive directors on the board increases the probability of performance enhancing measures (e.g., assets restructuring) being introduced to remedy an adverse financial position. Fama and Jensen ${ }^{27}$ further argue that, compared with internal directors, outside directors are more likely to have stronger incentives to develop reputations as decision control experts in order to enhance the market value of their human capital. As such, non-executive directors are expected to make a positive contribution to the achievement of cost efficiency in Takaful insurers. Indeed, Wang et $a l .{ }^{20}$ find a positive relation between the proportion of non-executive directors on the board and cost efficiency in non-life insurers operating in Taiwan. Therefore, our first hypothesis is:

H1a: Other things being equal, the cost efficiency scores of Takaful insurance firms will be positively related to the proportion of non-executive directors on the board.

While we expect that non-executive directors serve to mitigate managers' self-interest incentives, it is also worth pointing out that in Takaful insurance firms the excessive prudence and risk aversion of outside directors (that may be motivated by concerns about compliance with Shari'a principles) could at times be harmful to business decision-making and therefore cost efficiency scores. In view of this possibility an alternative hypothesis is:

H1b: Other things being equal, the cost efficiency scores of Takaful insurance firms will be inversely related to the proportion of non-executive directors on the board.

\section{Chief executive officer (CEO)/chairman positions}

Another issue of importance in the debate surrounding the effectiveness of boards of directors concerns the influence of the CEO, particularly where this person is also the Chairman, thereby consolidating the decision management and control functions. For instance, Hermalin and Weisbach ${ }^{28}$ suggest that CEOs who also retain the position of Chairman will tend to appoint non-executive directors who are unlikely to question proposals and business decisions, thus reducing their effectiveness as independent monitors of owners' economic interests. The merging of the $\mathrm{CEO} /$ Chairman positions could further restrict the dissemination of information to other board members thereby increasing the agency costs of managerial decision-making and blunting the effectiveness of the board's decisions. ${ }^{22,29}$ Hermalin and Weisbach ${ }^{28}$ consider that close monitoring by the Chairman and other board members could help to increases the effort expended by CEOs to maximise shareholders' wealth and avoid dismissal.

\footnotetext{
${ }^{26}$ Perry and Shivdasani (2005).

${ }^{27}$ Fama and Jensen (1983).

${ }^{28}$ Hermalin and Weisbach (1991).

${ }^{29}$ Raheja (2005).
} 
Rogers $^{30}$ further reports that the separation of the CEO/Chairman positions reduces the likelihood of high cash flow volatility arising from excessive risk-taking. This could be particularly important in Takaful insurers keen to avoid highly uncertain and risky situations (ghara). As a consequence, we hypothesize that:

H2a: Other things being equal, the cost efficiency scores of Takaful insurance firms will be higher where there is a separation of the CEO and Chairman positions.

On the other hand, there are counter-arguments on appointing a single individual as CEO and Chairman, such as the benefits of sure-footed decision-making and a centralized system of organisational command and control. ${ }^{31}$ As a result, we put forward an alternative hypothesis:

H2b: Other things being equal, the cost efficiency scores of Takaful insurance firms will be lower where there is a separation of the CEO and Chairman positions.

\section{Board size}

Researchers such as Pearce and Zahra, ${ }^{32}$ Yermack $^{33}$ and Raheja ${ }^{29}$ contend that board size can also be an important factor in determining the effectiveness of corporate governance. For example, Raheja ${ }^{29}$ suggests that large boards can provide additional expertise, extensive business networks and increased monitoring capacity. In fact, Pearce and $\mathrm{Zahra}^{32}$ find evidence supporting a positive relation between board size and performance in the U.S. corporate sector. Therefore, we propose the following hypothesis:

H3a: Other things being equal, the cost efficiency scores of Takaful insurance firms will be positively related to the size of the board of directors.

In contrast, Yermack ${ }^{33}$ provides U.S. evidence consistent with the view that small boards of directors are more effective than large boards. This is because large boards enhance the risk of conflicting opinions between board members, thereby promoting more efficient and effective decision-making. Jensen ${ }^{34}$ also observes that large governing boards face more coordination problems and so greater difficulties in making decisions than small boards of directors. Jensen ${ }^{34}$ recommends that corporate boards have a maximum of eight members. Therefore, an alternative hypothesis is:

H3b: Other things being equal, the cost efficiency scores of Takaful insurance firms will be inversely related to the size of the board of directors.

\footnotetext{
${ }^{30}$ Rogers (2002).

31 (For example, see Brickley et al. (1997).

32 Pearce and Zahra (1992).

33 Yermack (1996).

34 Jensen (1993).
} 


\section{Control variables}

Takaful insurers' cost efficiency scores could also be influenced by other firm-specific factors. In this study, we control for the effects of four main variables (i.e., ownership structure, firm size, product-mix and location). Our motivation for these variables is outlined below.

Zheka (p. 452) ${ }^{24}$ reports that, particularly in developing countries, company ownership can significantly affect financial performance by influencing managerial incentives, systems of monitoring and control, and the decision-making process. For example, ownership structure can affect the reported economic performance of Takaful insurers in that managers in firms with concentrated shareholdings are likely to be subject to greater monitoring and control by shareholders than their counterparts in firms with more widely held ownership structures. ${ }^{35}$ This is because in widely held firms, information asymmetries between shareholders and their agent managers is enhanced and individual small shareholders are frequently unwilling to bear the costs of monitoring, but rather "free ride" on the monitoring expenses of others. This reasoning suggests that, other things being equal, Takaful insurers with more concentrated shareholdings will be relatively more cost efficient than their counterparts with more diffuse ownership structures.

Fama and Jensen ${ }^{27}$ argue that enhanced business complexity could make monitoring managerial behaviour more difficult and less effective in large entities than in small companies. Therefore, firm size could be an important influence on the cost efficiency of Takaful insurance firms. Additionally, cost efficiency could also be achieved through firm size effects such as economies of scale and increased productmarket share. ${ }^{36}$ Indeed, Diacon et al. ${ }^{37}$ find evidence of firm size effects in their analysis of economic efficiency in European life insurance companies. As such, we control for firm size in the present study.

Khaled et $a .^{2}{ }^{2}$ report that product-mix could also influence the cost efficiency of insurance firms in that entities with a broad range of products can benefit not only from scale economies arising from increasing production, but also from economies of scope in the use of shared inputs (e.g., labour, technology and so on). Accordingly, we predict that multi-product Takaful insurers will be more cost efficient that their counterparts with more narrow lines of insurance business.

Finally, Takaful insurers operate across different jurisdictions with different degrees of regulation and tax rules which can impact on cost efficiency. Generally, better regulated jurisdictions will tend (e.g., for reputation enhancement purposes) to encourage resource use efficiency among the insurance firms that they supervise. ${ }^{20} \mathrm{We}$ thus control for location in the present study.

\footnotetext{
${ }^{35}$ Grossman and Hart (1980).

${ }^{36}$ Cummins (1999).

${ }^{37}$ Diacon et al. (2002).
} 


\section{Interaction terms}

Corporate governance structures are introduced to monitor managerial behaviour and control agency incentive conflicts. ${ }^{23}$ However, Barnhart and Rosenstein ${ }^{38}$ postulate that various governance mechanisms interact with each other in order to optimize prospective solutions to agency problems in firms. In other words, different governance mechanisms may substitute for and/or complement each other, and failure to control for the possible interaction among governance mechanisms may therefore result in misleading conclusions. For example, it could be that cost efficiency is affected by the proportion of non-executive directors on the board in conjunction with a CEO separate from the Chairman. Therefore, we introduce two-way multiplicative interactions between non-executive directors, CEO duality and board size to control such interactions.

\section{Estimating efficiency scores}

\section{$D E A$}

In this study we use non-parametric DEA to estimate the cost efficiency scores for Takaful insurers given the relatively small sample (i.e., a balanced panel 78 firm-years over the period 2004-2006) and the non-normal distribution of the underlying data. ${ }^{39}$ DEA is a linear programming methodology that enables efficiency scores for each firm in an industry to be estimated relative to a dominant set of efficient firms with similar characteristics. ${ }^{40}$ DEA is less demanding than parametric approaches in terms of the degrees of freedom, the form of the production function and error term assumptions. Furthermore, compared with parametric stochastic frontier methods, DEA uses individual observations rather than population averages, and focuses on revealed "best practice" firm efficiency frontiers rather than on the central tendency properties of firm efficiency frontiers (p. 453). ${ }^{24}$ These attributes are particularly advantageous in small sample studies such as the current research project. $^{41}$

The basic DEA formulation assumes that for a data set of $N$ Takaful insurance firms, each consuming different amounts of $m$ inputs to produce $s$ outputs, then:

$$
X_{i}=\left(x_{1 i}, x_{2 i}, \ldots x_{m i}\right)^{T} 0 \text { and } Y_{i}=\left(y_{1 i}, y_{2 i}, \ldots, y_{s i}\right)^{T} 0
$$

where $X_{i}$ and $Y_{i}$ denote the inputs and outputs of the $i$ th Takaful insurer. From eq. (1) the insurance production set that satisfies the assumptions of convexity, positive

\footnotetext{
38 Barnhart and Rosenstein (1998).

${ }^{39}$ We use a balanced panel to control for the potentially confounding effects of new entrants into, and exits out of, international Takaful insurance markets.

40 Sengupta (2002).

${ }^{41}$ For example, see also Cummins and Zi (1998); Cummins and Weiss (2001); Zheka (2005).
} 
monotonicity and the free disposability of inputs and outputs for all Takaful insurance firms in the panel data set can be expressed as:

$$
\begin{gathered}
T=\left\{(x, y): x \sum_{i=1}^{n} \lambda_{k} X_{k}, \quad y \leqslant \sum_{i=1}^{n} \lambda_{k} y_{k},\right. \\
\left.\sum_{i=1}^{n} \lambda_{k}=1 ; \lambda_{k} 0, i=1, \ldots, N\right\}
\end{gathered}
$$

where $\lambda_{k}$ are constants. From eq. (2), cost efficiency can be evaluated from the following variable returns to scale specification, proposed by Banker et al. ${ }^{42}$

$$
\begin{array}{ll}
\operatorname{Min} \theta & \\
\theta, \lambda & \\
\text { s.t. } & x_{0} \theta-X \lambda 0 \\
& Y \lambda y_{0} \\
& e^{T} \lambda=1 ; \lambda_{i} 0, i=1, \ldots N
\end{array}
$$

In Eq. (3), $X$ and $Y$ represent respectively primal vectors of inputs and outputs with columns $x_{i}$ and $y_{i}$; $\mathbf{e}$ is a vector of ones; $\lambda=\left(\lambda_{1}, \lambda_{2}, \ldots, \lambda_{n}\right)^{\mathrm{T}}$; and $\theta$ is an input radial measure of pure technical efficiency. When $\theta_{i}=1$, Takaful insurer $i$ is deemed to be on the boundary of total factor efficiency. However, as Schaffnit et al. ${ }^{43}$ make clear $\theta_{i}=1$ is a necessary but not a sufficient condition for a Takaful insurer to be technically efficient since $\left(x_{0}, y_{0}\right)$ may contain slack in its allocation of $m$-inputs and $s$-outputs. Thus, Takaful insurer $i$ is efficient only if $\theta_{i}=1, X \lambda=x_{0}, Y \lambda=y_{0}$ and inefficient when $\theta_{i}<1$.

Given input price data and assuming cost minimisation, pure technical, allocative and overall cost efficiencies can be estimated by running the following cost minimising DEA:

$$
\begin{aligned}
& \text { Min } w_{i}^{\prime} x_{j}^{*} \\
& \begin{array}{ll}
\lambda, x_{j}^{*} \\
\text { s.t. } \quad & x \lambda-y_{i} 0 \\
& x_{j}^{*}-X \lambda 0 \\
& e^{\mathrm{T}} \lambda=1 ; \lambda 0 ; i=1, \ldots m ;
\end{array}
\end{aligned}
$$

where $w_{i}$ is a vector of input prices and $x_{j}^{*}$ is the cost-minimising vector of input quantities for the $i$ th Takaful insurer, given input prices and the output levels $y_{i}$. Hence, for given input prices, pure technical and allocative efficiencies as well as measures of overall cost efficiencies can be derived for our sample of Takaful insurers from the use of the DEA procedures described above. ${ }^{44}$

\footnotetext{
42 Banker et al. (1984).

43 Schaffnit et al. (1997).

${ }^{44}$ The DEA is conducted using DEAP Version 2.1 developed by Coelli (1996).
} 
In conducting the DEA, we assume that Takaful insurers attempt to minimise the cost of employing various inputs to produce outputs, which are sold to policy-holders in an attempt to maximise profits.

\section{Variables and data}

To conduct our analysis we use a balanced panel data set of 78 firm-years for the period 2004-2006 comprising 26 Takaful non-life insurance companies of varying size, ownership structure and product-mix in each year. ${ }^{45}$ Financial data for these sample firms are reported in the World Islamic Insurance Directory. ${ }^{11}$ This period represents the earliest and latest periods for which complete information were available at the time the study was carried out, and comprises at least 20 per cent of the estimated total number of Takaful insurers currently operating globally. Our sample of companies also accounts for approximately two-thirds of annual premiums written in international Takaful insurance markets. Therefore, our sample is considered to be a fairly representative cross-section of the international Takaful insurance industry as a whole. Additionally, Takaful reinsurance companies and trust funds are excluded from the sample because they do not directly write much Takaful insurance, and often operate across international borders and so are not subject to many of the regulatory strictures (e.g., on premium rating) that can affect direct writers of Takaful insurance business. We further exclude the subsidiaries of foreign-owned multinationals to avoid the effects of transnational structures, operations and managerial practices possibly confounding our derived measures of cost efficiency. Finally, to allow standardization of analysis our financial data, were converted to U.S. dollars at the end-of-year exchange rates reported in the World Islamic Insurance Directory. ${ }^{11}$

We assume that Takaful insurers employ inputs of labour and capital to produce outputs in the form of non-life insurance policies. Since these outputs are intangible, they are difficult to measure. One approach is to identify the services that Takaful insurance companies provide and then derive proxies that are likely to be closely correlated with these services. Takaful insurance companies, like their Western counterparts, engage in risk-pooling and risk-bearing by selling insurance products in various lines of business such as motor and property insurance.

For the purposes of this study, we follow Bhatty (p. 14) ${ }^{10}$ and assume that non-life Takaful insurance firms produce four major risk-pooling and risk-bearing outputs: (a) motor vehicle insurance; (b) property (fire) insurance; (c) marine and aviation insurance; and (d) other insurance. Given the limited availability of data, we use "gross contributions" (i.e., gross premiums) to proxy the risk-pooling and risk-bearing outputs. We recognise that premium income as an output indicator is a measure of revenue and so represents price $\times$ quantity, rather than just quantity. The use of "incurred benefits" as a proxy for expected claims or losses has also been reported in

\footnotetext{
${ }^{45}$ While our study employs a small sample our data set it is nevertheless larger than that used in some previous insurance industry efficiency studies. For example, Wang et al's. (2007) DEA efficiency study of the Taiwanese non-life insurance industry used a balanced panel of 16 firms over the three years 2000 2002.
} 
the academic literature on the efficiency of insurance companies. ${ }^{46}$ However, we can rationalize the use of premiums as an output proxy since premiums are likely to be highly correlated with a company's expected losses.

In addition, we view Takaful insurance companies as using two key inputs, labour and capital, and total cost is measured by each company's total operating expenses. The price of labour is proxied by taking the estimated average wage rate per employee for each company (i.e. the estimated total wage bill divided by the number of employees). ${ }^{47}$ The capital input is computed as total capital expenses (equal to total operating costs minus labour costs) divided by an estimated cost of capital. ${ }^{48}$ These definitions enable us to compute input prices and quantities that vary across the Takaful insurance firms in the sample as well as over time. ${ }^{49}$

\section{Determinants of efficiency}

\section{Second-stage regression specification}

The dependent variables used in the second-stage regression analysis are the DEA cost efficiency scores. The independent variables are defined as follows:

- The proportion of non-executive directors on the board (NEXECS) is the ratio of the number of non-executive directors to the total number of board directors.

- The separation of the CEO and Chairman (CEO) is represented by a dummy variable where $\mathrm{CEO}=1$ for separate functions, and $\mathrm{CEO}=0$ otherwise.

- Board size $(B S I Z E)$ is the total number of directors on the board.

- Ownership structure $(O W N)$ is measured as the proportion of the total number of shares held by the top three shareholders.

- Firm size (LSIZE) is measured as the natural log of total assets.

- Product-mix $(M I X)$ is measured by a Herfindahl concentration index that is computed using the four major classes of products sold by our sample of Takaful insurers, namely: motor, property (fire), marine and aviation, and other insurance business. The Herfindahl index is computed for each company as: $M I X=\sum_{j=1}^{4} S_{j}^{2}$ where $S_{j}$ is the amount of annual premium income written in the $j$ th line of insurance divided by the total value of annual premium income for all four lines of business. The closer the Herfindahl index is to one, the more concentrated the product function of Takaful insurance firms.

\footnotetext{
${ }^{46}$ See, for example, Cummins (1999) and Cummins et al. (1999).

${ }^{47}$ Prior studies such as Khaled et al. (2001) suggest that labour costs typically constitute about 70 per cent of insurers annual management expenses. We thus compute labour costs for each firm in our sample as (management expenses $\times 0.70) \div$ total number of employees.

${ }^{48}$ Unfortunately the lack of publicly available data precluded a more precise measure of capital input (including financial capital) to be derived. A 12 per cent cost of capital was used to compute the value of capital, which is based on Kielholz's (2000) estimated average cost of capital for European insurers.

${ }^{49}$ Reinsurance being contingent capital can also affect the input efficiency of Takaful insurers. However, complete data on reinsurance premiums ceded to conventional reinsurance markets and Shari' $a$ compliant reinsurers were not available to us from public sources.
} 
- Location $(L O C)$ is a dummy variable where Takaful insurers located in jurisdictions with established regulatory and legislative systems (e.g., Bahrain, United Arab Emirates (UAE), Indonesia, and Malaysia) are coded 1 and 0 otherwise.

- Multiplicative interaction terms $(I T)$. These comprise the three interaction terms formed from pairs of NEXECS, CEO and BSIZE.

One issue associated with using multiplicative interaction terms between continuous variables in regression analysis is the potential multicollinearity problem arising from correlation between each interaction term (e.g., $N E X E C S \times C E O)$ and its constituent parts (e.g., NEXECS and CEO). We therefore follow the "centring" transformation procedure recommended by Jaccard et $a l .{ }^{50}$ This procedure involves "centring" corresponding continuous variables by subtracting sample means before constructing multiplicative interaction terms. The centred forms of the corresponding constituent variables are then used in the regression analysis. We find that such a transformation effectively reduces the correlation between the product term and the component variables.

Then we construct the following regression model:

$$
\begin{aligned}
y_{i t}{ }^{*}= & f\left(N_{E X E C S_{i t}}, C E O_{i t}, \operatorname{BSIZE}_{i t}, O W N_{i t}, \operatorname{LSIZE}_{i t},\right. \\
& \left.M I X_{i t}, L O C_{i t}, I T_{i t}, \text { year Dummies }\right)+u_{i}+v_{i t}
\end{aligned}
$$

where $y_{i t} *$ is the transformed cost efficiency score of the $i$ th Takaful insurer in year $t$ estimated from the first-stage analysis, with $f$ being a linear function. The error term, $u_{i}$ is a firm-specific intercept, and we assume that $u_{i} \sim N\left(0, \sigma_{u}^{2}\right)$ and that $v_{i t} \sim N\left(0, \sigma_{v}^{2}\right)$. The dependent variable $y_{i t}$ ranges from zero to one but there is no guarantee that estimates from a linear model will meet this restriction. Therefore, as in Cox (p. 33) we employ the logit transformation: $y_{i t}{ }^{*}=\ln \left[\left(y_{i t}+\left(2 n_{i}\right)^{-1}\right) /\left(1-y_{i t}+\left(2 n_{i}\right){ }^{1}\right)\right]$ to convert our cost efficiency scores into unrestricted variables that take values in the range $[-\infty,+\infty]$.

\section{Descriptive statistics and correlation coefficients for the second-stage regressions}

The descriptive statistics and correlation coefficients relating to the dependent and independent variables used in the second-stage regressions are presented in Table 1. In Panel A, the DEA efficiency scores (i.e. the dependent variables) are summarised in rows one to five. It is clear that Takaful insurers have consistently exhibited high levels of allocative efficiency (mean $=0.94$ with a standard deviation of only 0.08 ), but there is much more variation in the levels of technical efficiency, scale efficiency and overall cost efficiency. The mean overall cost efficiency score $(C E)$ for our sample of Takaful insurers $(0.70)$ is comparable with the average levels of cost efficiency reported in more developed non-life insurance markets that have employed DEA. For example, Hardwick and Guirguis ${ }^{52}$ report an average overall cost efficiency score of 0.66 for the

\footnotetext{
50 Jaccard et al. (1990).

${ }^{51}$ Cox (1970, p. 33).

${ }^{52}$ Hardwick and Guirguis (2007).
} 
Table 1 Descriptive statistics and correlation coefficients of variables for Takaful insurers in the secondstage regressions $(n=78$ observations)

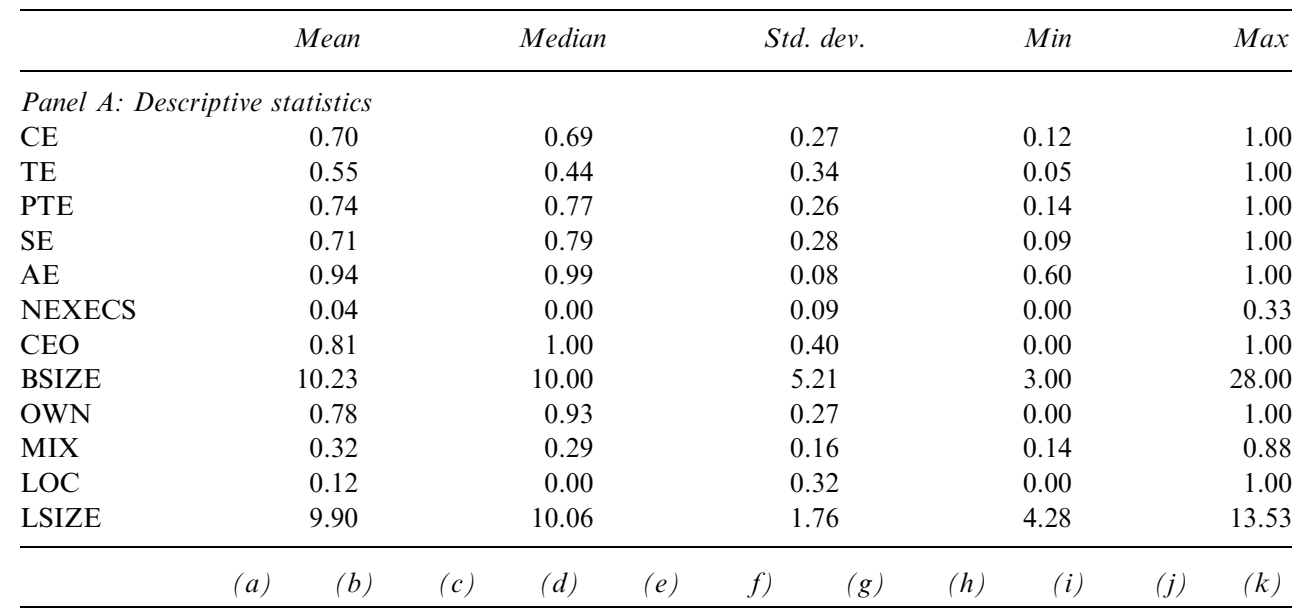

Panel B: Correlation coefficient matrix

\begin{tabular}{|c|c|c|c|c|c|c|c|c|c|c|c|c|}
\hline $\mathrm{CE}$ & (a) & 1.00 & & & & & & & & & & \\
\hline TE & (b) & $0.77^{\mathrm{a}}$ & 1.00 & & & & & & & & & \\
\hline PTE & (c) & $0.98^{\mathrm{a}}$ & $0.75^{\mathrm{a}}$ & 1.00 & & & & & & & & \\
\hline $\mathrm{SE}$ & (d) & $0.38^{\mathrm{a}}$ & $0.86^{\mathrm{a}}$ & $0.35^{\mathrm{a}}$ & 1.00 & & & & & & & \\
\hline $\mathrm{AE}$ & (e) & $0.56^{\mathrm{a}}$ & $0.42^{\mathrm{a}}$ & $0.42^{\mathrm{a}}$ & $0.31^{\mathrm{a}}$ & 1.00 & & & & & & \\
\hline NEXECS & (f) & -0.04 & -0.08 & -0.01 & -0.14 & $-0.29^{b}$ & 1.00 & & & & & \\
\hline CEO & (g) & $-0.30^{\mathrm{a}}$ & $-0.39^{\mathrm{a}}$ & $-0.29^{\mathrm{b}}$ & $-0.39^{\mathrm{a}}$ & $-0.23^{b}$ & 0.21 & 1.00 & & & & \\
\hline BSIZE & (h) & 0.03 & -0.03 & 0.03 & -0.06 & -0.17 & $0.53^{\mathrm{a}}$ & 0.06 & 1.00 & & & \\
\hline OWN & (i) & $0.49^{\mathrm{a}}$ & $0.31^{\mathrm{b}}$ & $0.52^{\mathrm{a}}$ & 0.05 & 0.01 & -0.13 & $-0.30^{\mathrm{b}}$ & 0.18 & 1.00 & & \\
\hline MIX & (j) & 0.10 & 0.14 & 0.12 & 0.09 & 0.04 & 0.05 & 0.00 & -0.16 & -0.20 & 1.00 & \\
\hline LOC & (k) & -0.12 & 0.04 & -0.14 & 0.12 & 0.05 & 0.22 & 0.18 & 0.21 & $-0.39^{\mathrm{b}}$ & -0.08 & 1.00 \\
\hline LSIZE & (1) & $0.41^{\mathrm{a}}$ & $0.66^{\mathrm{a}}$ & $0.39^{\mathrm{a}}$ & $0.67^{\mathrm{a}}$ & $0.31^{\mathrm{a}}$ & 0.14 & $-0.27^{\mathrm{b}}$ & $0.20^{\mathrm{c}}$ & 0.18 & $-0.25^{\mathrm{b}}$ & $0.33^{\mathrm{a}}$ \\
\hline
\end{tabular}

Notes: CE, SE, AE, PTE, and TE=overall, scale, allocative, pure technical and technical scores computed using DEA ; $N E X E C S=$ the proportion of non-executive directors on the board; $C E O=$ dummy variable, $1=$ the separation of the CEO from board Chairman, $0=$ otherwise; $B S I Z E=$ the number of directors on the board; $O W N=$ the proportion of the total shares held by the top three shareholders; $M I X=$ product mix, measured by a Herfindahl concentration index; $L O C=$ dummy variable, $1=$ insurers located in jurisdictions with established regulatory and legislative systems, $0=$ otherwise; $L S I Z E=$ natural $\log$ of size, measured by total assets. Average value of total assets for unlogged $S I Z E$ for our sample of Takaful insurers is U.S.\$71.5 million.

Pearson correlation coefficients are computed between metric variables and Spearman-rank correlation coefficients are computed between $C E O$ and LOC and their correlation with other variables. $\mathrm{a}, \mathrm{b}$, and c statistically significant at 1, 5 and 10 per cent level (two-tailed), respectively.

U.K. non-life insurance industry, and Wang et al. ${ }^{20}$ report an average overall cost efficiency score of 0.72 in their analysis of cost efficiency in the Taiwanese non-life insurance industry.

Turning to the independent variables, we see that average board size (BSIZE) is just over 10 members. This figure is more than the maximum board size $(n \leqslant 8)$ recommended by Jensen ${ }^{34}$ but nonetheless consistent with that reported by Wang 
et $a .^{20}$ (where the average board size=11). Additionally, in our data set of Takaful insurers non-executive directors on average account for a very small proportion of board directors (approximately 4 per cent of board directors). This proportion is much less than the mean of 40 per cent of outside director representation in U.K. life and non-life insurers reported in O'Sullivan and Diacon. ${ }^{53}$ Additionally, firm size ( $L S I Z E)$ varies more substantially than the other variables in our data set (logged standard deviation $=1.76$ ) with most firms in our sample being small to medium-sized insurance companies by international standards (with an (unlogged) average total asset value of U.S.\$71.5 million). The descriptive statistics further reveal that 12 per cent of Takaful insurance firms in our sample are located in jurisdictions with established regulatory and legislative systems and 81 per cent separate the CEO and Chairman positions.

Panel B of Table 1 presents the correlation coefficients between efficiency scores and the various board characteristics and control variables. Panel B of Table 1 shows that the proportions of non-executive to executive directors on the board appear to be low but negatively related to the cost efficiency scores of Takaful insurance firms. The negative and statistically significant correlations (at $\mathrm{p} \leqslant 0.05$ or better, two-tail) between the variable $C E O$ and our cost efficiency scores suggests that Takaful insurers with separate $\mathrm{CEO}$ and Chairman functions are less efficient than their counterparts that do not have a separate CEO and Chairman. This finding suggests that combining the CEO and Chairman functions might actively help improve the cost efficiency of Takaful insurers (e.g., by reducing the possibility of conflicting decisions). In addition, the positive correlation between $L S I Z E$ and cost efficiency scores suggest that large Takaful insurance firms appear to be more cost efficient than small firms.

Overall, the correlation coefficients between pairs of explanatory variables reported in Table 1, Panel B are generally modest with the strongest correlation coefficient value of 0.53 (significant at $p \leqslant 0.01$ level, two tailed) being between $B S I Z E$ and $N E X E C S$, suggesting that serious multicollinearity is unlikely. On the other hand, collinearity can be present between more than two explanatory variables at the same time. However, upon computing the variance inflation factors (VIF) for these variables, we find that the calculated VIFs for all variables are less than the recognised threshold of $10 .^{54}$ The VIFs therefore appear to confirm our view that multicollinearity is not a problem in the present study.

\section{Second-stage regression results}

To enable us to investigate the joint influence of all the independent variables on the cost efficiencies of Takaful insurers we report random-effects rather than fixed-effects panel estimations for two main reasons: (a) some board characteristics (e.g., CEO and NEXECS) have very limited time-series variations; and (b) Zhou ${ }^{55}$ argues that a fixed-effects estimation that removes within-firm differences may not be

\footnotetext{
${ }^{53}$ O'Sullivan and Diacon (2003).

${ }^{54}$ For example, see Kennedy (1998, p. 213).

55 Zhou (2001).
} 
Table 2 Random-effects regression results: Board characteristics and cost efficiencies of Takaful Insurers ( $N=78$ observations)

\begin{tabular}{|c|c|c|c|c|c|c|c|c|c|c|c|}
\hline \multirow[t]{3}{*}{ Dependent var. } & \multirow[t]{3}{*}{ Beta ref. } & \multicolumn{2}{|c|}{$C E$} & \multicolumn{2}{|c|}{$T E$} & \multicolumn{2}{|c|}{$P T E$} & \multicolumn{2}{|c|}{$S E$} & \multicolumn{2}{|c|}{$A E$} \\
\hline & & \multicolumn{2}{|c|}{ (1) } & \multicolumn{2}{|c|}{ (2) } & \multicolumn{2}{|c|}{ (3) } & \multicolumn{2}{|c|}{ (4) } & \multicolumn{2}{|c|}{ (5) } \\
\hline & & Coeff. & $S E$ & Coeff. & $S E$ & Coeff. & $S E$ & Coeff. & $S E$ & Coeff. & $S E$ \\
\hline \multicolumn{12}{|c|}{ Panel A: Regression coefficients } \\
\hline NEXECS & b1 & 3.14 & 3.98 & 0.84 & 3.73 & 3.55 & 4.03 & -2.14 & 2.73 & -0.70 & 1.89 \\
\hline $\mathrm{CEO}$ & b2 & -0.10 & 0.71 & -0.08 & 0.68 & -0.14 & 0.73 & -0.20 & 0.49 & -0.04 & 0.33 \\
\hline BSIZE & b3 & $0.10^{\mathrm{b}}$ & 0.07 & $0.09^{\mathrm{b}}$ & 0.06 & 0.08 & 0.07 & $0.07^{\mathrm{c}}$ & 0.05 & $0.05^{\mathrm{b}}$ & 0.03 \\
\hline OWN & b4 & $3.24^{\mathrm{a}}$ & 1.15 & $2.15^{\mathrm{b}}$ & 1.08 & $3.16^{\mathrm{a}}$ & 1.16 & 0.46 & 0.79 & 0.27 & 0.54 \\
\hline MIX & b5 & $2.85^{\mathrm{b}}$ & 1.43 & $5.31^{\mathrm{a}}$ & 1.12 & $2.89^{\mathrm{b}}$ & 1.37 & $4.12^{\mathrm{a}}$ & 0.91 & 0.24 & 0.84 \\
\hline LOC & b6 & 0.02 & 1.12 & -0.25 & 1.05 & -0.20 & 1.13 & -0.07 & 0.77 & 0.20 & 0.53 \\
\hline LSIZE & b7 & $0.30^{\mathrm{b}}$ & 0.18 & $0.84^{\mathrm{a}}$ & 0.15 & $0.29^{\mathrm{b}}$ & 0.17 & $0.81^{\mathrm{a}}$ & 0.12 & $0.14^{\mathrm{c}}$ & 0.09 \\
\hline NEXECS $\times$ BSIZE & b8 & -0.93 & 0.81 & $-1.93^{\mathrm{a}}$ & 0.76 & -0.80 & 0.82 & $-1.77^{\mathrm{a}}$ & 0.56 & $-0.49^{\mathrm{c}}$ & 0.38 \\
\hline $\mathrm{CEO} \times \mathrm{BSIZE}$ & b9 & -0.05 & 0.20 & -0.08 & 0.19 & -0.06 & 0.20 & -0.04 & 0.14 & -0.02 & 0.09 \\
\hline Constant & - & $-4.61^{\mathrm{a}}$ & 2.00 & $-10.40^{\mathrm{a}}$ & 1.69 & $-4.15^{\mathrm{b}}$ & 1.96 & $-7.80^{\mathrm{a}}$ & 1.31 & 0.97 & 1.09 \\
\hline Year dummies & & Yes & & Yes & & Yes & & Yes & & yes & \\
\hline $\operatorname{Adj}-R^{2}$ & & 0.44 & & 0.70 & & 0.43 & & 0.77 & & 0.25 & \\
\hline$\sigma_{u}^{2}$ & & 1.04 & & 1.08 & & 1.14 & & 0.51 & & 0.09 & \\
\hline$\sigma_{v}^{2}$ & & 1.19 & & 0.59 & & 1.02 & & 0.42 & & 0.67 & \\
\hline
\end{tabular}

Notes: CE, SE, AE, PTE, and TE= logistically transformed overall, scale, allocative, pure technical and technical scores computed using DEA; NEXECS = the proportion of non-executive directors on the board; $\mathrm{CEO}=$ dummy variable, $1=$ the separation of the CEO from board Chairman, $0=$ otherwise; $\mathrm{BSIZE}=$ the number of directors on the board; $\mathrm{OWN}=$ the proportion of the total shares held by the top three shareholders; MIX = product mix, measured by a Herfindahl concentration index; LOC $=$ dummy variable, $1=$ insurers located in jurisdictions with established regulatory and legislative systems, $0=$ otherwise;

LSIZE $=$ natural log of size, measured by total assets.

a, b, c statistically significant at 1, 5 and 10 per cent level (one-tailed).

The continuous variables (e.g., NEXECS) that enter multiplicative interactions are centred (i.e., subtracting sample mean) before constructing interactions. The centred form of these continuous variables is also used in the regression. Our regression model is expressed as: $y_{i t}{ }^{*}=f\left(N E X E C S_{i t}, C E O_{i t}, B S I Z E_{i t}, O W N_{i t}, L S I Z E_{i t}\right.$, $M I X_{i t}, L O C_{i t}, I T_{i t}$, year Dummies) $+u_{i}+v_{i t}$.

able to detect the effects of board characteristics (e.g., CEO) with limited variations (as is the case in this study).

Table 2, Panel A reports five model estimations using our five cost efficiency measures as dependent variables. The existence of statistically significant interaction terms between some board characteristics implies that the effects of some board characteristics could be conditional on other governance mechanisms. As noted by Jaccard et $a l .{ }^{50}$ in the presence of interaction terms, the relation between an explanatory variable (e.g., $N E X E C S$ ) and the dependent variable (cost efficiency) needs to be evaluated together with the estimated coefficients on the interaction terms. So the coefficient of $N E X E C S$ is $b 1+b 8 \times B S I Z E$. This means that the NEXECS-CE, NEXECS-TE, NEXECS-PTE, NEXECS-SE, and NEXECS-AE relations are likely to vary according to the number of directors on the board.

Regarding $\mathrm{H} 1$, the proportion of non-executive directors on the board (NEXECS), although positively signed, is not statistically significant in any of the regression 
models suggesting that outside directors are not effective contributors to cost efficiency in Takaful insurance firms. Furthermore, the interaction term $N E X$ $E C S \times B S I Z E$ is negative and statistically significant in relation to the technical, scale and allocative cost efficiency of Takaful insurers (at $p \leqslant 0.10$ or better, one tail) (regression models 2, 4 and 5). As predicted by $\mathrm{H} 1 \mathrm{~b}$, this observation suggests that non-executive directors may actually hinder the realization of cost efficiency in Takaful insurers possibly because of a lack of financial expertise and familiarity with the business of risk management and insurance.

Regarding $\mathrm{H} 2$, the separation of the CEO and board Chairman positions $(C E O)$ is found to have a negative but insignificant effect on cost efficiency. The interaction term $C E O \times B S I Z E$ is also negatively signed but not statistically significant in all five regression estimates indicating that separating the CEO and Chairman functions, even in Takaful insurance firms with large boards, does not contribute to improving cost efficiency.

Board size is found to have a positive and statistically significant effect on the cost efficiency of Takaful insurers (at $p \leqslant 0.10$ or better, one tail) as predicted by $\mathrm{H} 3 \mathrm{a}$ for all aspects of cost efficiency except pure technical efficiency (regressions 1, 2, 4 and 5). This finding suggests that Takaful insurers that are able to draw from a larger pool of board-level executive expertise are likely to be relatively more efficient in their allocation and use of resource inputs than Takaful insurers that are managed by small boards of directors.

Turning to the control variables, the estimated coefficient for $O W N$ is positive and statistically significant in regression models 1,2 , and 3 (at $p \leqslant 0.05$ or better, one tail), suggesting that Takaful insurers with more concentrated shareholders will be more cost efficient than their counterparts with more diffuse ownership structures. This can occur because firms with concentrated shareholdings are more likely to be subjected to a great monitoring and control by shareholders thus reducing information asymmetry problems and agency incentive conflicts. ${ }^{35}$ Moreover, the estimated coefficient for LSIZE is positive and statistically significant in all regressions. This is consistent with our findings of a generally positive relation between board size and cost efficiency reported above (given that firms with larger boards also tend to be bigger entities). This suggests that large Takaful insurance firms are more cost efficient than small firms-for example, because as reported in Diacon et al. ${ }^{37}$ increased company size can enhance operational efficiency through economies of scale. However, the estimated coefficient for $M I X$ is positive and statistically significant (at $p \leqslant 0.05$ or better, one-tail) suggesting that less diversified Takaful insurers are more cost efficient than Takaful insurers with a more varied mix of outputs. This result suggests that, contrary to the predictions of Khaled et $a .^{2}$ Takaful insurers do not appear to be optimizing shared inputs across the different ranges of insurance products that they offer and as a consequence, are not realizing the benefits of scope economies. Instead, cost efficiencies appear to accrue from product specialization. Finally, we find no statistically significant evidence to support the notion that better regulated jurisdictions tend to promote better resource use efficiency among Takaful insurers. Hence, we find no support for a connection between the cost efficiency of Takaful insurance companies and their location. 


\section{Conclusion}

This study applies DEA to examine the cost efficiency among a balanced panel of 26 Takaful insurers operating in 10 Islamic countries over the three years 2004-2006. We find that non-executive directors do not appear to contribute positively to cost efficiency and that in fact, they may engender cost inefficiencies in Takaful insurers with large boards. This could possibly reflect a lack of financial management expertise among the non-executive directors of Takaful insurance firms. Additionally, the separation of the CEO and Chairman functions does not help to improve the cost efficiency of Takaful insurers. Therefore, the separation of the CEO and Chairman, which is a commonly cited governance mechanism in the Western literature, may not be appropriate in Takaful insurance markets given their unique institutional features and product-market structure. However, we find that board size and firm size have positive effects on the cost efficiency of Takaful insurers suggesting that larger firms are better placed than smaller entities to realize operational improvements because they can draw upon the expertise of a wider pool of experienced and financially skilled executive directors. Furthermore, cost efficiencies appear to emerge from specialized product lines rather than more diversified outputs indicating that economies of scope are not being fully realized by Takaful insurers. Finally, the effect of regulatory environment is found not to be statistically significant.

We believe that our results could have important commercial and policy implications. For example, improving the appointment of skilled and experienced nonexecutive directors to the board, and clarifying their role in advising on operational and strategic matters such resource allocation and usage could be a potentially important policy-making implication of our research. Furthermore, regulators in Takaful insurance markets need to be appreciative of the importance of improving the operational efficiency of Takaful insurers' use and allocation of inputs, particularly capital. This would help to improve solvency and ensure better economic returns for shareholders and policy-holders. We acknowledge that interpretation of the results of our study may need to be tempered by recognition of the inherent limitations of our research design such as the small sample size and limited financial data that are publicly available. However, we have attempted to control for these limitations where possible in order to derive reliable and robust results (e.g., by adopting a panel data design). Finally, we consider that our research lays the foundations for further research to be carried out on the Takaful insurance industry, which is poised to become one of the major emerging international markets for insurance over the next decade or so.

\section{References}

Abouzaid, C. (2007) 'The role of pure Re-Takaful operators versus conventional reinsurers: Envisioning the future', in S. Jaffer (ed) Islamic Insurance: Trends, Opportunities and the Future of Takaful, London: Euromoney, pp. 63-71.

Banker, R.D., Charnes, A. and Cooper, W.W. (1984) 'Some models for estimating technical and scale inefficiencies in data envelopment analysis', Management Science 30(9): 1078-1092.

Barnhart, S.W. and Rosenstein, S. (1998) 'Board composition, managerial ownership and firm performance: An empirical analysis', The Financial Review 33(4): 1-16. 
Berger, A.N. (1993) 'Distribution-free estimates of efficiency in the U.S. banking industry and tests of the standard distributional assumptions', Journal of Productivity Analysis 4: 261-292.

Bhatty, A. (2007) 'The growth and global market for Takaful', in S. Jaffer (ed) Islamic Insurance: Trends, Opportunities and the Future of Takaful, London: Euromoney, pp. 3-21.

Brickley, J.A., Coles, J.L. and Jarrell, G.A. (1997) 'Leadership structure: separating the CEO and Chairman of the board', Journal of Corporate Finance 3(3): 189-220.

Coelli, T.J. (1996) A guide to DEAP version 2.1: A data envelopment analysis (Computer) program, CEPA Working Paper No. 96/081, Department of Econometrics, University of New England.

Cox, D.R. (1970) The Analysis of Binary Data, London: Chapman and Hall.

Cummins, J.D. (1999) 'Efficiency in the U.S. life insurance industry: Are insurers minimizing costs and maximizing revenues?', in J.D. Cummins and A.M. Santomero (eds) Changes in the Life Insurance Industry: Efficiency, Technology and Risk Management, Norwell, MA: Kluwer Academic Press.

Cummins, J.D. and Weiss, M.A. (2000) 'Analyzing firm performance in the insurance industry using frontier efficiency and productivity methods', in G. Dionne (ed) Handbook of Insurance, Boston, MA: Kluwer Academic Publishers.

Cummins, J.D. and $\mathrm{Zi}$, H. (1998) 'Measuring economic efficiency of the U.S. life insurance industry: Econometric and mathematical programming techniques', Journal of Productivity Analysis 10: 131-152.

Cummins, J.D., Tennyson, S. and Weiss, M.A. (1999) 'Consolidation and efficiency in the U.S. life insurance industry', Journal of Banking and Finance 23: 325-357.

Diacon, S.R., Starkey, K. and O'Brien, C.D. (2002) 'Size and efficiency in European long-term insurance companies: An international comparison', The Geneva Papers on Risk and Insurance-Issues and Practice 27(3): 444-466.

Fama, E. and Jensen, M.C. (1983) ‘Agency problems and residual claims', Journal of Law and Economics 26: 327-352.

Grossman, S. and Hart, O. (1980) 'Takeover bids, the free rider problem, and the theory of the corporation', Bell Journal of Economics 11(1): 42-64.

Hardwick, P. 1997 'Measuring cost efficiency in the U.K. life assurance industry', Applied Financial Economics 7: 37-44.

Hardwick, P. and Guirguis, M. (2007) 'The U.K. insurance industry - structure and performance', in J.D. Cummins and B. Venard (eds) Handbook of International Insurance: Between Global Dynamics and Local Contingencies, New York: Springer Publications.

Hermalin, B.E. and Weisbach, M.S. (1991) 'The effects of board composition and direct incentives on firm performance', Financial Management 20: 101-112.

Hossain, M., Cahan, S.F. and Adams, M.B. (2000) 'The investment opportunity set and the voluntary use of outside directors: New Zealand evidence', Accounting and Business Research 30: 263-273.

Islam, M.M. (2003) 'Regulations and supervision of financial institutions in GCC countries', Managerial Finance 29: 17-42.

Jaccard, J., Turrisi, R. and Wan, C.K. (1990) Interaction Effects in Multiple Regression, Sage University Paper Series on Quantitative Applications in the Social Sciences: 07-069 Newbury Park, CA: Sage Publications.

Jensen, M.C. (1993) 'The modern industrial revolution, exit, and the failure of internal control systems', Journal of Finance 48: 831-880.

Jensen, M.C. and Meckling, W.H. (1976) 'Theory of the firm: managerial behavior, agency costs and ownership structure', Journal of Financial Economics 3: 305-360.

Kassim, Z.A.M. (2007) 'Takaful: A question of surplus', in S. Jaffer (ed) Islamic Insurance: Trends, Opportunities and the Future of Takaful, London: Euromoney, pp. 48-52.

Kennedy, P. (1998) A Guide to Econometrics, Oxford: Blackwell.

Khaled, M., Adams, M.B. and Pickford, M. (2001) 'Estimates of scale and scope economies in the New Zealand life insurance industry', The Manchester School 69: 327-349.

Khorshid, A. (2004) Islamic Insurance: A Modern Approach to Islamic Banking, New York: Routledge.

Kielholz, W. (2000) 'The Cost of Capital for Insurance Companies', The Geneva Papers on Risk and Insurance-Issues and Practice 25(1): 4-24.

Klumpes, P.J.M. (2005) 'Managerial use of discounted cash flow or accounting performance measures: Evidence from the U.K. life assurance industry', The Geneva Papers on Risk and Insurances-Issues and Practice 30(1): 171-186. 
180

Maysami, R.C. and Kwon, W.J. (1999) 'An analysis of Islamic Takaful insurance', Journal of Insurance Regulation 18: 109-132.

Nelson, J. (2005) 'Corporate governance, CEO characteristics and firm performance', Journal of Corporate Finance 11: 197-228.

O'Sullivan, N. and Diacon, S.R. (2003) 'Board composition and performance in life insurance companies', British Journal of Management 14: 115-129.

Pearce, J. and Zahra, S. (1992) 'Board composition from a strategic contingency perspective', Journal of Management Studies 29: 411-438.

Perry, T. and Shivdasani, A. (2005) 'Do boards affect performance? Evidence from corporate restructuring', Journal of Business 78(4): 1403-1431.

Pi, L. and Timme, S.G. (1993) 'Corporate control and bank efficiency', Journal of Banking and Finance 17: 515-530.

Raheja, C.G. (2005) 'Determinants of board size and composition: A theory of corporate boards', Journal of Financial and Quantitative Analysis 40: 283-306.

Rediker, K.J. and Seth, A. (1995) 'Boards of directors and substitution effects of alternative governance mechanisms', Strategic Management Journal 16: 85-99.

Rogers, D. (2002) 'Does executive portfolio structure affect risk management? CEO risk-taking incentives and corporate derivatives use', Journal of Banking and Finance 26: 271-295.

Sengupta, J.K. (2002) 'Economics of efficiency measurement by the DEA approach', Applied Economics 34: 113-1139.

Schaffnit, C., Rosen, D. and Paradi, J.C. (1997) 'Best practice analysis of bank branches: An application of DEA in a large Canadian bank', European Journal of Operational Research 98: 269-289.

Swiss Re (2008) Insurance in the Emerging Markets: Overview and Prospects for Islamic Insurance, Sigma No. 5, Zurich: Swiss Re Publications.

Thompson, S. and Wright, M. (1995) 'Corporate governance: The role of restructuring transactions', Economic Journal 105: 690-703.

Wang, J.L., Jeng, V. and Peng, J.L. (2007) 'The impact of corporate governance structure on the efficiency performance of insurance companies in Taiwan', The Geneva Papers on Risk and Insurances-Issues and Practice 32(2): 264-282.

World Islamic Insurance Directory (2008) Takaful Re/Insurance Communications, UAE: World Islamic Insurance Directory.

Yermack, D. (1996) 'Higher market valuation of companies with a small board of directors', Journal of Financial Economics 40: 185-211.

Zheka, V. (2005) 'Corporate governance, ownership structure and corporate efficiency: The case of Ukraine', Managerial and Decision Economics 26: 451-460.

Zhou, X.M. (2001) 'Ownership and performance: Comment', Journal of Financial Economics 62: 559-571.

\section{About the Authors}

Hale Abdul Kader is the Agnes Hempsell Endowed Doctoral Scholar at the Centre for Risk and Insurance Studies. Nottingham University Business School. Her published works include articles on cost efficiency of Takaful Insurers (Geneva Association/ International Insurance Society Research Excellence Prize Winner 2009); the reinsurance in the Swedish fire insurance market in the interwar years; and the reinsurance and taxation in the U.K. life insurance industry. She is also a member of the U.K.-based female insurance executive organization, the Women's Insurance Network, and is assistant examiner in finance on the external degree programme run by the London School of Economics.

Mike Adams is Chair of Finance at the School of Business \& Economics, Swansea University. His research interests are in the economics and finance aspects 
of insurance and risk. He has published in leading academic journals such as the Journal of Financial \& Quantitative Analysis, Journal of Banking \& insurance, Journal of Risk \& Insurance, Journal of Financial intermediation, among others. He is also the U.K.'s Academic Ambassador for the International Insurance Society (www.lisomline.org) and a member of the Willis Research Network (www.willis researchnetwork.com).

Philip Hardwick is Chair of Financial Services at the Business School, Univeristy of Bournemouth. His research interests are in the economic efficiency of financial services companies. He has published in leading academic journals including Journal of Business Finance \& Accounting, Journal of Banking \& Finance, Journal of Risk \& Insurance, Oxford Economic Papers, among others. 